STATE OF OREGON

DEPARTMENT OF GEOLOGY AND MINERAL INDUSTRIES

910 State Office Building

1400 SW Fifth Avenue

Portland, Oregon 97201

\title{
FIELD GEOLOGY OF THE
}

\section{NORTHWEST QUARTER OF THE BROKEN TOP 15' QUADRANGLE, DESCHUTES COUNTY, OREGON}

\author{
By Edward M. Taylor, \\ Associate Professor of Geology, \\ Oregon State University \\ Publication funded by U.S. Department of Energy \\ Grant No. DE-FG07-84 ID 12526 \\ Published in conformance with ORS 516.030
}

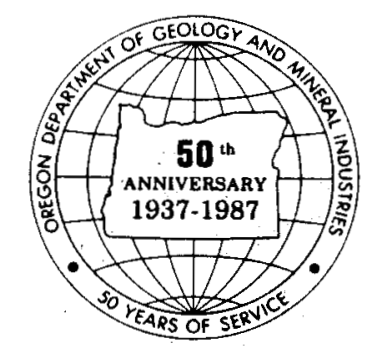




\section{DISCLAIMER}

This report was prepared as an account of work sponsored by an agency of the United States Government. Neither the United States Government nor any agency Thereof, nor any of their employees, makes any warranty, express or implied, or assumes any legal liability or responsibility for the accuracy, completeness, or usefulness of any information, apparatus, product, or process disclosed, or represents that its use would not infringe privately owned rights. Reference herein to any specific commercial product, process, or service by trade name, trademark, manufacturer, or otherwise does not necessarily constitute or imply its endorsement, recommendation, or favoring by the United States Government or any agency thereof. The views and opinions of authors expressed herein do not necessarily state or reflect those of the United States Government or any agency thereof. 


\section{DISCLAIMER}

Portions of this document may be illegible in electronic image products. Images are produced from the best available original document. 


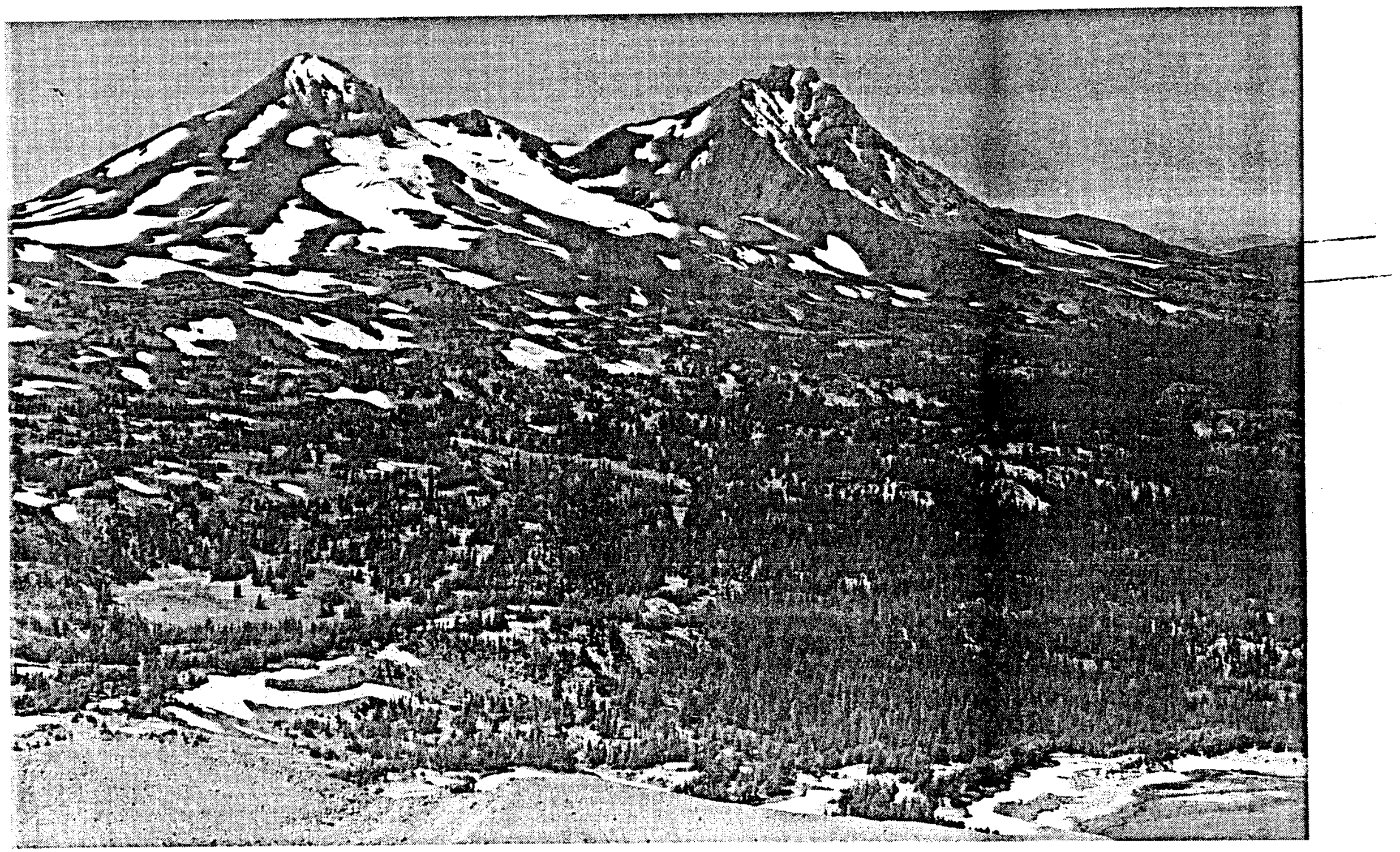

Frontispiece. Eastern slopes of Middle Sister (left) and North Sister volcanoes. Pleistocene lava flows and glaciers descended from these peaks onto the more gentle terrane of N.W. Broken Top quadrangle (forested foothills). 


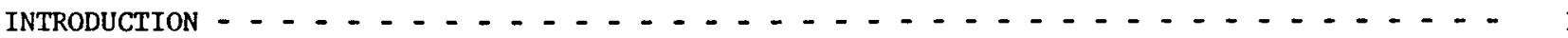

GENERAL GEOLOGY OF N.W. BROKEN TOP QUADRANGLE - - - - - - - - - - - - - - - - 1 Prequaternary Volcanism and Subsidence - - - - - - . - - - - - - - - - 1

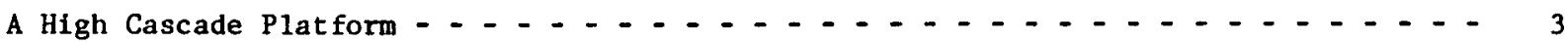
Centers of Silicic Volcanism - - - . - - . - - - - - - - - - - - 3 Glaciation _. . . . . . . . . . . . . . . . . . . . . . . 4

GEOLOGIC MAP OF N.W. BROKEN TOP QUADRANGLE - - - - - - - - - - - - - - - - - 4

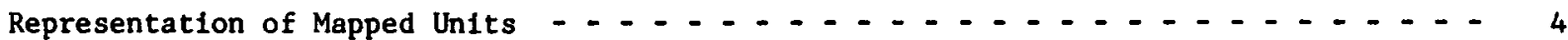
Age - - - - - - - - - - - - - - - - - - - - - - - - - - 5 Composition - - - - - - - - - - - - - - - - - - - - - - 5 Occurrence of Volcanic Deposits - - - - - - - . - . - - - - - - - - 5 Occurrence of Nonvolcanic Deposits - $-\ldots+\ldots$

DESCRIPTIONS OF MAPPED UNITS - - - - - - - - - - - - - - - - - - - - 7 Nonvolcanic Deposits - - - - - - - - - - - - - - - - - - - - - - 7 Units of Pleistocene Basalt - - - - - - - - - - - - - - - - - - - 8 Units of Pleistocene Basaltic Andesite - - - - - - - - - - - - - - - 8 Units of Pleistocene Andesite - - - - - - . - - - - - - - - - - - 12 Units of Pleistocene Rhyodacite - $\ldots+\ldots+\ldots$

REFERENCES - - - - - - - - - - - - - - - - - - - - - - - 13

ACKNOWLEDGEMENT - $-\ldots \ldots+\ldots$

APPENDIX 1. Chemical Analyses of Rocks from N.W. Broken Top Quadrangle - - - - - - 15

APPENDIX 2. Locations of Analysed Rocks from N.W. Broken Top Quadrangle - - - - - - 18

PLATE 1. Geologic Map of N.W. Broken Top Quadrangle

\section{DISCLAIMER}

This report was prepared as an account of work sponsored by an agency of the United States Government. Neither the United States Government nor any agency thereof, nor any of their employees, makes any warranty, express or implied, or assumes any legal liability or responsibility for the accuracy, completeness, or usefulness of any information, apparatus, product, or process disclosed, or represents that its use would not infringe privately owned rights. Reference herein to any specific commercial product, process, or service by trade name, trademark, manufacturer, or otherwise does not necessarily constitute or imply its endorsement, recommendation, or favoring by the United States Government or any agency thereof. The views and opinions of authors expressed herein do not necessarily state or reflect those of the United States Government or any agency thereof. 


\title{
FIELD GEOLOGY OF N.W. BROKEN TOP QUADRANGLE, OREGON
}

\author{
INTRODUCTION
}

The following report is a complation of geologic field observations and supporting laboratory data obtained during a study of the eastern slope of the High Cascade Range of Oregon, north of Broken Top volcano (Figure 1). General geologic relationships are summarized, then followed by 1ithologic descriptions, petrographic characteristics, and stratigraphic information, cross-indexed to tables of chemical analyses of pertinent rock units. This is the second report of a series in which the objective is to place a large body of data on record in a form readily accessible to those whose interests range from general geology of the central High Cascades to specialized study of 1 ts many challenging geologic problems.

GENERAL GEOLOGY OF N.W. BROKEN TOP QUADRANGLE

The 7.5-minute N.W. Broken Top quadrangle is bounded by $44^{\circ} 07^{\prime} 30^{\prime \prime}$ and $44^{\circ} 15^{\prime} 00^{\prime \prime}$ north 1 at 1 tude and by $121^{\circ} 37^{\prime} 30^{\prime \prime}$ and $121^{\circ} 45^{\prime} 00^{\prime \prime}$ west longitude, $6 \mathrm{~km}$ east of North and Middle Sister volcanoes and $35 \mathrm{~km}$ northwest of Bend (Figure 1). The quadrangle is covered by glacial till and calc-alkaline lavas, most of which orfginated on the adjacent slopes of the High Cascades. Basalt, basaltic andesite, andesite, and rhyodacite are represented in a variety of forms including lava flows, volcanic domes, cinder cones, and a welded ash-flow tuff.

\section{Prequaternary Volcanism and Subsidence}

Volcanic rocks older than several hundred thousand years are not exposed in N.W. Broken Top quadrangle. However, Prequaternary magmatism and tectonism indirectly influenced later volcanic activity of the entire central High Cascades. Late Mlocene and early Pliocene High Cascade volcanism is recorded in volcanic and sedimentary deposits of the Deschutes Formation, east and northeast of the Broken Top area. An integrated study of the stratigraphy, petrology, sedimentology, and geochronology of these rocks (Smith, Snee, and Taylor, 1987) has demonstrated that a great volume of volcaniclastic material was delivered to the eastern slope of the central Cascades during an interval that began $7.4 \mathrm{million}$ years ago. The source volcanoes of this ancestral Cascade Range subsided into a fault-bounded depression approximately $5.4 \mathrm{million}$ years ago. Products of continued eruptions were largely trapped within a graben and accumulation of Deschutes Formation volcaniciastic sediments outside of the graben was sharply reduced. The eastern boundary of the graben is most obvious in the 750-meter west-facing escarpment of Green Ridge, $40 \mathrm{~km}$ north of Broken Top. Existence of this fault system within older rocks beneath N.W. Broken Top quadrangle is speculative. However, it is of significance that upper Deschutes Formation volcaniclastic deposits, including welded ash-flow tuffs and coarse air-fall pumice beds several meters thick are exposed along the Deschutes River as far south as Bend. A $6 \mathrm{~km}^{2}$ inlier of Deschutes Formation welded tuffs and andesitic lavas, simflar to those of Green Ridge, exists at an elevation of 4400 feet in the Bull Springs area, only $17 \mathrm{~km}$ east of Broken Top. Consequently, the possibility of an extension of the Pllocene High Cascade graben south of Green Ridge into the Broken Top area cannot be dismissed without additional data. 


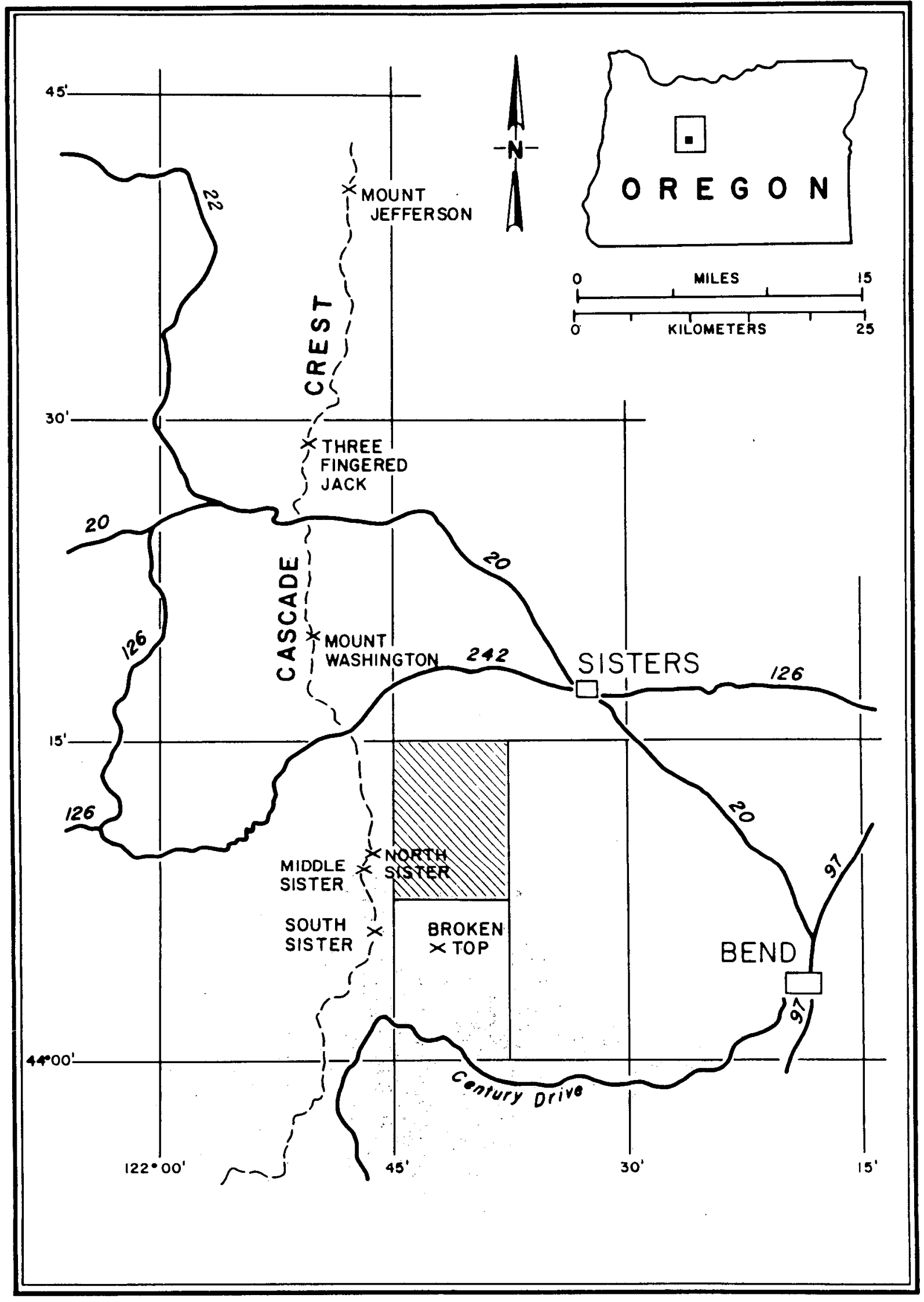

Figure 1. Location of N.W. Broken Top Quadrangle. 


\section{A High Cascade Plat form}

The Pliocene High Cascade graben was filled with volcaniclastic deposits and mafic lavas which probably ascended through elongate north-south dikes controlled by intra-graben faults. During Pleistocene time, the graben was buried beneath a broad platform of overlapping shield volcanoes which obscured all but the most prominent fault escarpments. Widespread sheets of diktytaxitic basalt were important components of the graben $\mathrm{f111}$; in N.W. Broken Top area these are represented by the Spruce Spring basalts. Continued construction of this platform produced broad shields with large sumnit cones such as North Sister, moderate-sized shields such as Trout Creek Butte, and small cinder cones with associated lava flows such as Millican Crater, Pole Creek cone, and Black Pine Spring cone (P1ate 1).

Stratigraphic relationships suggest that most of the High Cascade mafic platform rocks exposed in N.W. Broken Top quadrangle have been produced in the last 0.2 million years. Isotopic age of the Tumalo rhyodacite ash-flow tuff near Bend is $0.29 \pm 0.12$ million years (Sarna-Wojcicki and others, 1987). A succession of ash beds, pyroclastic flows, mafic lavas, and alluvial deposits occurs between the Tumalo Tuff and overlying Shevlin Park Tuff, which is exposed in N.W. Broken Top quadrangle. Many units of High Cascade platform basaltic andesite separate the Shevlin Park Tuff from overlying North Sister lavas. Consequently, the entire North Sister (oldest of the Three Sisters. volcanoes) and much of the platform on which 1 t stands are of very late Pleistocene age.

Basaltic andesite lava flows and cinder cones continued to erupt on the platform through Holocene time. Fine-grained mafic ash from Yapoah and Collier cones fell over the northwest part of the N.W. Broken Top quadrangle 2000-3000 years ago, as determined by C-14 ages of logs charred by hot cinders near these cones (Taylor, 1968).

\section{Centers of Silicic Volcanism}

Silicic volcanism appears to have been concentrated in the Three Sisters area for the last several milition years. Many silicic ash-flow tuffs of the Deschutes Formation flowed in valleys descending northeast, away from the site now occupied by Three Sisters volcanoes (Smith, 1986). Andesitic, dacitic, and rhyodacitic ash-flow tuffs spread over the Bend area from now-buried source vents to the west. Silicic vents at South Sister, Middle Sister, and Broken Top have been active during Pleisocene and Holocene time.

The eastern slope of the High Cascades becomes steeper and protrudes eastward into the Deschutes Valley between Bend and Broken Top. This extension of the Cascade plat form was produced by emplacement of multiple volcanic domes of dacitic and rhyodacitic composition, which built a silicic highland (Taylor, 1978). The $0.3 \mathrm{Ma}$ Tumalo Tuff was vented from this highland; its magmatic volume has been estimated to be at least 10 cublc $\mathrm{km}$ (Hi11, 1985). Four other ash-flow tuff sheets of similar origin have been Identified (Taylor, 1980); one of these (Sheviln Park Tuff) clearly erupted from a vent now buried beneath Triangle Hill cinder cone group on the edge of the highland (Taylor, 1981). Most of the silicic highland is now mantled by mafic lavas and cinder cones. However, glaciated canyons such as those occupied by Tumalo Creek and Squaw Creek have been cut into the margins of the highland, exposing silicic lavas and ash-flow tuffs. In the N.W. Broken Top quadrangle, the westernmost known occurrence of Shevlin Park Tuff has been exposed in the North Fork of Squaw Creek. Also, the west edge of the Three Creek Butte group of rhyodactte domes rises above fields of mafic lava. Rhyodactic lavas exposed at Squaw Creek Falls and near the confluence of Squaw Creek and the North Fork of Squaw Creek are a late addition to the silicic highland. In the vicinity of Tam McArthur Rim, northeast of Broken Top, a varied assemblage of andesitic, dacitic, and rhyodactic dikes, lavas, and domes, coeval in part with Broken Top volcano, probably constitutes a post-highland episode of silicic eruptions.

The youngest volcanic rocks in N.W. Broken Top quadrangle were products of South Sister eruptions. After a transitional andesite-dacite lava (PsAnLal1) moved into the Squaw Creek valley, a series of 
Pleistocene rhyodacite domes was constructed along the east base of South Sister from Devils Hill on the south to Chambers Lakes area on the north. This was followed by andesite lava (PsAnLal) which also entered Squaw Creek valley. Approximately 2000 years ago, rhyodacitic volcanism was renewed along the east base of South Sister (Scott, 1987) and pumiceous tephra from this source can be found in solls as far north as Demaris Lake.

\section{Glaciation}

Glacial drift in the form of moraines and outwash covers a major part of N.W. Broken Top quadrangle. These deposits record the advance of Pleistocene glaciers down to elevations of approximately 4400 feet. The entire east Cascade slope was covered; the most active streams of ice converged from Three Sisters and Broken Top into the canyon of Squaw Creek where multiple sets of lateral moralnes now rise $250 \mathrm{~m}$ above the valley floor.

Squaw Creek morainal deposits are similar to those of the Suttle Lake member of Cabot Creek Formation of Wisconsin age east of Mount Jefferson (Scott, 1977) and probably were emplaced during the interval 75,000-12,000 years B.P. (Bacon, 1983; Shackleton and Opdyke, 1973). Although moraines of greater age are preserved on the northwest side of Trout Creek Butte, it is remarkable that earlier glacial episodes are not abundantly recorded on the east slope of this part of the Cascade Range. The Three Sisters and Broken Top stratocones, and the Cascade platform on which they stand, might not have reached sufficient elevation in earlier Pleistocene time to support extensive glacial systems.

Minor Neoglacial advances are recorded by fresh moraines and outwash above timberline on the east side of North and Middle Sisters. At the highest level, these moraines are fresh, nondissected, and are not mantled with volcanic ash; they are probably less than 2000 years old. At lower levels, more extensive moraines support a thin, incipient soil mixed with Holocene volcanic ash from South Sister flank eruptions (approximately 2000 years B.P.). In the upper Soap Creek drainage on the east side of North Sister, a four-fold set of nested Neoglacial moraines is preserved. At the northeast base of North Sister one of these moraines is overla1n by ash from Mount Mazama (6800 years B.P., Bacon, 1983).

GEOLOGIC MAP OF N.W. BROKEN TOP QUADRANGLE

Distribution of volcanic and nonvolcanic deposits is represented on Plate 1 , a geologic map of the 7.5-minute N.W. Broken Top quadrangle. Symbols representing mapped units are described below. Other map symbols are explained in the map legend.

\section{Representation of Mapped Units}

In the text of this report and on the accompanying geologic map, symbols representing volcanic rocks convey four categories of information: age, composition, occurrence, and unit number. For example, "PsBALa35" designates the thirty-fifth numbered Pleistocene basaltic andesite lava flow and "PsBAPc35" designates the cinder cone from which that lava issued. This notation does not conform to established geologic map symbols used by U.S. Geological Survey and Oregon Department of Geology and Mineral Industries. It is employed here because conventional symbols such as "Qob" (Quaternary olivine basa1t) or "Qtbv" (P1locene and Pleistocene basaltic vent rocks) are not appropriate to a systematic distinction of the several hundred different volcanic units which are to be presented in this serles of reports on field geology of the central Cascade Range. 
Rocks older than a few hundred thousand years are not exposed in the N.W. Broken Top quadrangle. Moreover, none of the lavas were erupted after retreat of Pleistocene glaciers, approximately 12,000 years ago. Consequently, only Neoglacial drift, alluvium, and recent ash deposits are of Holocene age; all surface lavas are Pleistocene.

Ho: Holocene deposits. Includes Neoglacial deposits, alluvium, and volcaniclastic rocks less than 12,000 years old.

Ps: Pleistocene deposits. Includes glacial deposits, f1ow rocks, and volcaniclastic material older than 12,000 years but less than 1.6 million years.

\section{Composition}

Because many glassy Cascade rocks cannot be characterized adequately by mineralogical criterfa, chemical composition is a more sultable basis for general rock nomenclature. In this study, five-wefghtpercent increments of silica content are assigned to basalt (48-53), basaltic andesite (53-58), andesite (58-63), dacite (63-68), and rhyodacite (68-73+). Many High Cascade rocks contain more than 73 percent silica but none should be designated "rhyolite" unless it also contains more than 4 percent potash. These values are simflar to sflica subdivisions used for rocks of Mount Hood (Wise, 1969) and Mount Mazama (Bacon, 1983); they are not in serious conflict with previously published petrographic names of rocks from the central Cascades (Willlams, 1944).

Bs: Basalt, 53 or less welght percent $\mathrm{SiO}_{2}, \mathrm{H}_{2} \mathrm{O}$-free.

BA: Basaltic andesite, 53-58.

An: Andesite, 58-63.

Da: Dacite, 63-68.

Rd: Rhyodacite, 68 or more weight percent $\mathrm{SiO}_{2}$ and $\mathrm{K}_{2} \mathrm{O}$ less than 4 percent.

Occurrence of Volcanic Deposits

Volcanic rocks in the N.W. Broken Top quadrangle occur in the form of extrusive lava flows and volcanic domes, ash-flow tuffs, ash-fall deposits, near-vent agglomerates, and cinder cones.

La: Lavas. Includes volcanic domes, single flows, and composite flows in which pyroclastic material is subordinate.

Pc: Coarse pyroclastic deposits. Includes fresh or plalagonitized scoria and agglomerate of cinder cones in which pyroclastic material is predominant.

P1: Ignimbritic deposits, both welded and nonwelded, of pyroclastic-flow origin.

\section{Occurrence of Nonvolcanic Deposits}

Mapped nonvolcanic deposits are represented by symbols which designate age and occurrence only. Unit numbers are given to these deposits if they possess characteristics that require separate description. 


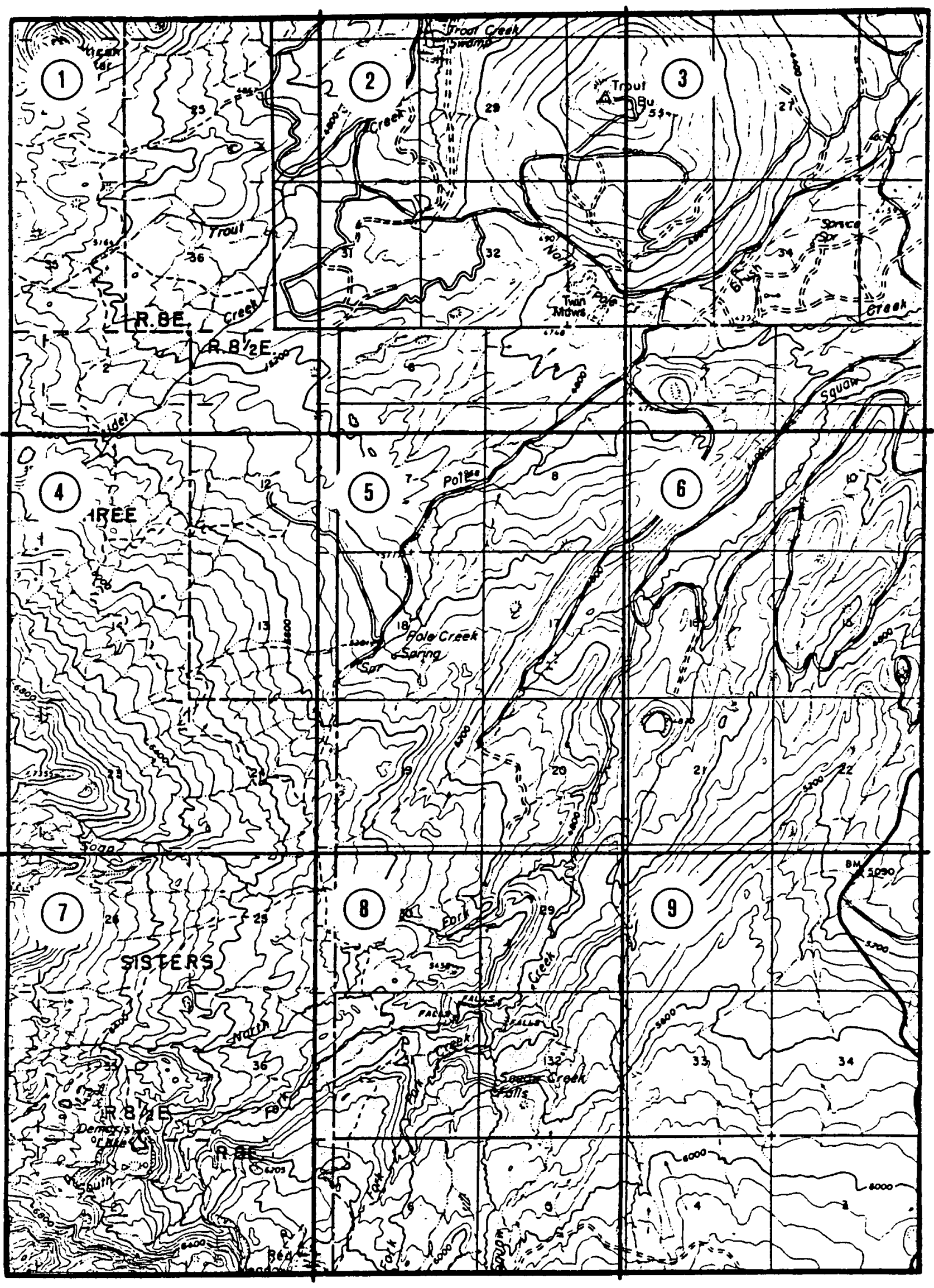

Figure 2. Index to Geologic Map Subdivisions, N.W. Broken Top Quadrangle. 
Al: Alluvium. Includes well-sorted glacial outwash, flood deposits; silt, sand, and gravel of stream and lake beds.

Gd: Glacial drift. Includes t111 of terminal, lateral, and ground moraines, and some poorly sorted outwash near terminal moraines.

Ta: Talus. Includes extensive aprons of talus, talus ramparts, and block fields.

Sn: "Permanent" snow fields.

\section{DESCRIPTIONS OF MAPPED UNITS}

Distinctive field and lithologic features of mapped units are summarized below in consecutively numbered age-composition groups. Each unit is numbered on the geologic map (Plate 1 ) and appropriate geologic map subdivision numbers (Figure 2) are included in each description. Consequently, a description of any given mapped untt is easily found and the mapped locations of each described deposit are readily identifled. Unit numbers are continued from the preceding contribution of this series (Taylor, 1978).

Petrographic characteristics were determined through study of thin sections of fresh, nonvesicular glassy samples taken from widely separated parts of each unit. Phenocryst proportions were measured by standard point-counting techniques and are reported as volume percent of solid rocks, excluding vold spaces. Compositions of plagloclase are reported as mole percent An and were determined by measurement of extinction angles according to the method of combined albite and Carlsbad twins, the a-normal method, and the Michel Levy method, in that order of preference. Charts published by Tobi (1963), Von Burri and others (1967), and Shelley (1975) for volcanic plagioclase were used in support of these methods, respectively.

Silica content is given for each described unit as well as the sample numbers of pertinent chemical analyses and calculated averages. All analyses are listed by sample number in Appendix 1 , corresponding to Appendix 2, sample locations. Each sample site is also identified by number on the geologic map (Plate 1). Analytical values are expressed as weight percent oxides of the eight major cations $\mathrm{Si}, \mathrm{Ti}, \mathrm{Al}, \mathrm{Fe}, \mathrm{Mg}, \mathrm{Ca}, \mathrm{Na}$, and $\mathrm{K}$. All iron is expressed as FeO. Each analysed sample was split from at least $0.5 \mathrm{~kg}$ of uniform rock powder and was converted to an anhydrous condition. A lithium borate fusion technique was used to prepare sample powders for $x$-ray emission spectrometry of $\mathrm{Si}, \mathrm{TI}, \mathrm{Al}, \mathrm{Fe}, \mathrm{Ca}$, and $\mathrm{K}$. This was followed by atomic absorption spectrophotometry of $\mathrm{Mg}$ and $\mathrm{Na}$. All determinative procedures were calibrated to a set of U.S. Geological Survey analysed rock standards. Replicate analyses have established that results are reproducible to within $1.0,0.05,0.5,0.1,0.1$, $0.1,0.1$, and 0.05 of the respectively tabulated values. Analyses were performed by E. M. Taylor.

\section{Nonvolcanic Deposits}

HoGdl Terminal and lateral Neoglacial moraines and associated glaclal drift on the east slopes of HoGd2 Middle Sister and North Sister. Slight alteration and development of thin, incipient soil horfzons containing fragments of pumice and volcanic ash characterize deposits of HoGdl. Fresh moraines of HoGd2 occur at higher elevations west of N.W. Broken Top quadrangle and are not mantled by volcanic ash.

PsGd Terminal and lateral late Pleistocene moraines and associated glacial drift. Morainal deposits are widely distributed over N.W. Broken Top quadrangle and consist of unsorted, rounded to subangular clasts of volcanic rocks suspended in a matrix of sand and silt that has been 
altered to a depth of 0.5-1 meters. Multiple sets of moraines occur to elevations as $10 w$ as 4400 feet. Forested, hummocky topography with bogs and alluviated depresstons is common.

Units of Pleistocene Basalt

PsBsLa4 Olivine-bearing diktytaxitic basaltic lavas of Spruce Spring. Silica 51-52. Highly vesicu-

lar black lavas of conspicuously coarse groundmass. Phenocrysts of olivine (2-3\%; up to 3 $\mathrm{mm}$ ) and plagioclase (less than $1 \%$; An 70-65; oscillatory zones in normal progression to sharp narrow rims of An 50 ; up to $4 \mathrm{~mm}$ ). Groundmass is composed of An 50-45 plagioclase in stout prisms up to $2 \mathrm{~mm}$ long with close-set polysynthetic twinning, in an intergranular relationship to dark colored granules of clinopyroxene. Olivine, magnetite, and films of black glass are minor components of the groundmass. Part of an assemblage of diktytaxitic basaltic lavas which is widespread north and northeast of the mapped area. Overlain by lavas and ash from Trout Creek Butte (PsBALa29); rests upon basaltic lava of Brush Draw (PsBsla5). Normal paleomagnetic polarity. Analyses 59, 61, 257; average 1039. Geologic map subdivisions 2,3 , and quadrangle east.

PsBsLa5 Olivine- and clinopyroxene-bearing basaltic lava of Brush Draw. Silica.52-53. Blocky, black lavas with brownish-yellow weathered surfaces. Phenocrysts of plagioclase (14-15\%; An 65-60 cores with thin rim zone of An 55; up to $4 \mathrm{~mm}$ ), olivine (2\%; up to $2 \mathrm{~mm}$ ), and clinopyroxene ( $2 \%$; up to $4 \mathrm{~mm}$ ). Groundmass composed of An 55-50 microlites of plagloclase with intergranular clinopyroxene, magnetite, and olivine. Unusually high $\mathrm{CaO}$ content and large phenocrysts of clinopyroxene. Overlain by diktytaxitic basalt of Spruce Spring (PsBsLa4). Normal paleomagnetic polarity. Analysis 36. Geologic map subdivision 3 and quadrangle east.

PsBsLa6 Basalt porphyry of Middle Sister. Silica 52-53. Black, vesicular, ropy surfaces on branching flows composed of overlapping bulbous protrusions 1-2 m thick. Phenocrysts and glomerocrysts of plagloclase (30-40\%; chfefly uniform An 62-58; some crystals contain partly resorbed cores of An 80 , mantled by broad An 60 rims; elongate tabular morphology, up to $10 \mathrm{~mm}$ ), and olivine (8-10\%; Fo 75; euhedral, up to $5 \mathrm{~mm}$ ). Groundmass conslsts of plagioclase microlites (An 61), fibers of clinopyroxene, olivine granules, and skeletal magnetite suspended in black glass. Erupted from numerous dikes concentrated within 7200-8400' elevation on N., W., S., and S.E. slopes of Middle Sister. Normal paleomagnetic polarity. Average of 11 analyses of this unit from Middle Sister: 1052 . Small glaciated remnant lava overlies PsBALa36 in geologic map subdivision 7.

\section{Units of Pleistocene Basaltic Andesite}

PsBALa3 Orthopyroxene-bearing basaltic andesite lavas northwest and north of Park Meadow. Silica

56-57. Gray to brown, scoriaceous to platy lavas with glaciated remnants of pressure ridges. Phenocrysts of plagioclase (27-29\%; An 55-35 in osc1llatory normal zones; up to $2 \mathrm{~mm}$ ), orthopyroxene, and microphenocrysts of magnetite (both 1-2\%). Also contains sparse phenocrysts of large resorbed plagioclase with patchy zoning and glomerocrysts of plagloclase and two pyroxenes, up to $6 \mathrm{~mm}$. Groundmass plagioclase An 35. Overlain by andesite lavas from South Sister (PsAnLa1); rests upon rhyodacite lavas of Squaw Creek Falls (PsRdLal4). Analysis 210. Geologic map subdivision 8 and quadrangle south.

PsBALa7 Small, 1solated outcrops of glaclated basaltic andesite lava north of Snow Creek Ditch. Silica 56. Phenocrysts of plagioclase $(1-2 \%$; resorbed cores of An 70 normally zoned to rims of An 65; up to $2 \mathrm{~mm}$ ), olfvine (up to $3 \mathrm{~mm}$ ), and traces of clinopyroxene. Probably from a small glactated cinder cone remnant (PsBAPc7) $0.8 \mathrm{~km}$ south of geologic map subdivision 9 . Analyses 150 and 368 ; average 1050. Geologic map subdivision 9. 
PsBALa11 Orthopyroxene- and olivine-bearing basaltic andesite microporphyritic lavas from Broken Top volcano. Silica 54-56. Gray and black vesicular flows containing up to $60 \%$ phenocrysts, glomerocrysts, and microphenocrysts of plagioclase, olivine, two pyroxenes, and magnetite, often in two generations. A more complete description has been given by Taylor (1978). Average composition of 19 lavas: 1013. Geologic map subdivision 8 and quadrangle south.

PsBALa26 Basaltic andesite lava of Black Crater. Silica 55-57. Lavas gray to black, glaciated, vesicular. Sparse phenocrysts of plagioclase (An75-65; uniform normal zoning to a thin rim which is zoned An 65-50; up to $2 \mathrm{~mm}$ ) and even less abundant clinopyroxene (up to $0.5 \mathrm{~mm}$ ). Groundmass of An 45 plagioclase laths with intergranular pyroxene and magnetite. Normal paleomagnetic polarity. Analyses 6, 16; average 1036. Geologic map subdivision 1 and quadrangle north.

PsBALa27 0livine-bearing basaltic andesite lava and pyroclastic deposits of Millican Crater.

PsBAPc27 Silica 53-54. Lavas red and scoriaceous near source, gray and moderately vesicular away from cone. Glomerocrysts up to $4 \mathrm{~mm}$ composed of plagloclase (12-15\%; An 85-75; continuous normal zoning; up to $1 \mathrm{~mm}$ ) and olivine $(2-3 \%$; up to $0.3 \mathrm{~mm})$. Cone is composed of black and red cinders and bombs, glaciated on lower flanks. Millican flows rest upon lavas from Black Crater (PsBALa26) and are overlain by lavas from Matthieu Lakes Cone (PsBALa28). Isolated outcrops that are surrounded by glacial drift in NE $\frac{1}{2}$ of $\sec 31$, T.15 S., R.9 E. probably are part of this unit. Normal paleomagnetic polarity. Analyses 373, 375, 489; average 1037. Geologic map subdivisions 1, 2.

PsBALa28 Basaltic andestte lava from Matthieu Lakes Cone. Silica 56-57. Thick, platy flows extend $15 \mathrm{~km}$ from cone on Cascade crest line, northeast to Cold Springs on Highway 242. Flow surface is extensively glaciated above $3800^{\prime}$ elevation but beyond reach of Pleistocene glaclers, it is covered with relatively fresh scoria and blocks. Phenocrysts of plagioclase (normal zoning, An 65-45), clinopyroxene, and olivine are all small and make up less than 1 percent. Pyroxene is more abundant near the source and olivine is more abundant near the terminus. Gray to black, fine-grained pilotaxitic groundmass of plagioclase (An 45), pyroxene, magnetite, and glass. Overlies lava from Millican Crater (PsBALa27). Normal paleomagnetic polarity. This flow is typlcal of many central High Cascade units which display enrichment in $\mathrm{Fe}$ and $\mathrm{Ti}$ relative to depleted $\mathrm{Mg}$. Analyses $35,37,60,77,264,374$, and 492; average 1038. Geologic map subdivisions 1, 2, and quadrangles $W$. and $N$.

PsBALa29 Basaltic andesite lavas of Trout Creek Butte. Silica 56-57. Gray to black vesicular lavas with sparse phenocrysts and glomerocrysts of plagioclase (An 65-50; oscillatory zones in normal progression; up to $1 \mathrm{~mm}$ ) and olivine (up to $2 \mathrm{~mm}$ ). Clinopyroxene phenocrysts occur in some flows on lower flanks. Groundmass composed of An 50-45 plagloclase laths with intergranular clinopyroxene, magnetite, olivine, and interstitial glass. Trout Creek Butte is a well preserved shield volcano, 4-5 km in diameter; it lacks a sumit cone. Latest Pleistocene moraines were deposited along W., S.W., and S. sides of the butte; an older moralne of unknown age covers the N.W. base. Ash from Trout Creek Butte is widespread for several $\mathrm{km}$ to the E. and N. E., which implies that a summit cinder cone was a prominent feature at some stage of development. Normal paleomagnetic polarity. Analysis 9 . Geologic map subdivisions 2,3 , and quadrangles N., N.E., and E.

PsBALa30 Basaltic andesite lava and pyroclastic deposits from Pole Creek Cone. Silica 57. Black PsBAPc 30 to gray platy lavas and red scoria. Plagioclase phenocrysts occur in two generations: (1) less than $1 \%$ stout phenocrysts, up to $4 \mathrm{~mm}$ long. They are nearly uniform An 55 but contain faint oscillatory zoning and are partly resorbed; (2) $12-15 \%$ microphenocrysts less than 0.5 $\mathrm{mm}$ long. They are also An 55 but are not zoned and not resorbed. Clinopyroxene and olivine microphenocrysts make up less than 1 percent. Cone rests on diktytaxitic basalt of Spruce Spring (PsBsLa4) and lava from the cone is overlain by late Pleistocene glacial drift. Normal paleomagnetic polarity. Analyses 66, 69, 214; average 1040. Geologic map subdivision 3 and quadrangle east. 
PsBALa31 Olivine-bearing basaltic andesite lavas of North Sister (east slope, not separately mapped).

Silica 54-55. Lavas black to gray, vesicular with "salt-and-pepper" appearance due to abundant plagloclase microphenocrysts and glomerocrysts. Phenocrysts of plagioclase and olivine up to $4 \mathrm{~mm}$ pass gradationally to predominant microphenocrysts less than $0.5 \mathrm{~mm}$ in size. Total phenocrysts and microphenocrysts often make up 30-45\% of North Sister lavas. Larger plagioclase crystals contafn partly resorbed normally zoned cores of An 80-75 surrounded by broad rims of An 55-50; smaller crystals are nearly uniform An 55-50 and are not resorbed. 01ivine phenocrysts make up 3-5\% of most flow units and range in size from 0.5 to $3 \mathrm{~mm}$. Early flows, especially on the southeast flank, contain more and larger glomerocrysts and phenocrysts of plagloclase and olivine, and contain slightly more Mgo than later flows. Groundmass consists of An 50 plagloclase microlites, olivine, clinopyroxene, magnetite, and glass in textures that range from intergranular to micro-ophitic.

A few North Sister flows accumulated in depressions to form thick lava lakes. Glaciated remnants of these units resemble plug rocks, as in the valley of Alder Creek (geologic map subdivsion 4). Groundmass is uniformly coarse grained $(0.5-1.5 \mathrm{~mm})$ and outcrops display smooth, rounded surfaces, stained yellow by deuteric alteration of olivine.

North Sister lavas are overlain by lavas from Middle Sister. Normal paleomagnetic polarity has been found in all of 13 units tested. Analyses of lavas and dikes from the east half of North Sister include: $38,212,213,256,307,376,378,379,543,544,545,546,547$, 548; average 1041. Geologic map subdivisions $1,4,5,7$, and quadrangle west.

PsBALa32 Olivine-bearing basaltic andesite lavas at the confluence of Snow Creek and Squaw Creek. Silica 53-54. Coarsely porphyritic, vesicular, gray to black. Weathered surfaces are reddish brown. Phenocrysts of plagioclase (30-34\%; An 60-55; mottled, patchy zoning obscures faint oscillatory zones in cores; up to $7 \mathrm{~mm}$ ) and olivine ( $3-4 \%$; up to $1 \mathrm{~mm})$. Hyalophitic groundmass conconsists of An 55 plagioclase laths, clinopyroxene, and magnetite in dark glass. Overlain by intracanyon andesite lavas of Squaw Creek (PsAnLall) and underlain by andesite lavas of lower Squaw Creek (PsAnla10). Normal paleomagnetic polarity. Analysis 211. Geologic map subdivisions $5,6$.

PsBALa33 Basaltic andesite lavas exposed on west side of Squaw Creek Canyon between 4600 ' and $5000^{\prime}$ elevation, not separately mapped. S1lica 53-55. Many dark- to light-gray flows, 6-10 m thick, with close-set platy jointing above a basal scoria, grading into blocky jointed interiors. Top flow beneath Shevlin Park Tuff in N. Fork of Squaw Creek canyon contains xenoliths of granodiorite. Some flows contain phenocrysts of plagioclase (up to 15\%; normally zoned An 80 to 55 ; $5 \mathrm{~mm}$ long) with clinopyroxene and olivine (both less than $1 \%$ but up to $4 \mathrm{~mm}$ ); other flows are essentially aphyric with only sparse microphenocrysts of plagloclase. The groundmass of most of these flows consists of An 55 plagioclase with intergranular pyroxene and magnetite; some flows contain abundant orthopyroxene. Glass is usually present only at the top and bottom of the flow units. Overlain by Shevlin Park Tuff (PsAnP112) and underlain by andesite of lower Squaw Creek (PsAnLa10). Six of the flow units were found to possess normal paleomagnetic polarity. Analyses 217, 218, 224. Geologic map subdivisions 5 and 8 .

PsBALa34 Basaltic andesite lavas exposed in glaciated cliffs on the east side of Squaw Creek canyon from 4400 to 5200' elevation, not separately mapped. Silica 56-58. Many dark- to 11ghtgray flows, 10-20 m thick, with blocky jointed interiors and platy jointed bases. Where these flows have been traced eastward beyond the reach of Pleistocene glaclation, surfaces are scorlaceous and pressure ridges are still preserved. Flow units are nearly aphyric with less than $1 \%$ microphenocrysts of An 45-50 plagloclase, clinopyroxene, magnetite, and traces of olivine. Groundmass is very fine grained, intergranular, and pilotaxitic. Distribution, petrography, and chemical composition suggest that these flows were produced from a cinder cone east of Rim Lake (PsBAPc5 in S.W. Broken Top quadrangle, Taylor, 1978). Normal paleomagnetic polarity. Analyses 221, 222, 223, 236, 240; average 1043. Geologic map subdivisions $5,6,8,9$, and quadrangle east. 
PsBALa35 Basaltic andesite cinder cone and lavas of Black Pine Spring. Silica 54-55. Cone of red PsBAPc 35 and black scoria, approximately $150 \mathrm{~m}$ high, is surrounded and nearly buried on all but the northeast side by Pleistocene moralnes and glacial drift. This is the source cone of a thick lava flow which extends $10.9 \mathrm{~km}$ northeast and $1 \mathrm{~s}$ displaced near its terminus by a reactivated segment of the Tumalo Fault. Phenocrysts of plagioclase (less than 1\%; cores and rims An 60 , 1ntermediate zones An 75) and microphenocrysts of clinopyroxene and olivine (both less than $1 \%$ ). Very finegrained pilotaxitic groundmass. An outcrop of basaltic andesite lava surrounded by glacial drift in north central section 15, T.16 S., R.9 E., 1s chemically and petrographically similar to these lavas except for larger $(3 \mathrm{~mm}$ ) and more abundant (up to $1 \%$ ) plagioclase phenocrysts. Overlain by Shevlin Park Tuff (PsAnPi12). Normal paleomagnetic polarity. Analyses 51, 70, 73, 82, 231, 234 ; average 1044. Geologic map subdivision 6 and quadrangle east.

PsBALa36 Basaltic andesite lavas west and northeast of Demaris Lake, not separately mapped. S1lica 55-57. Flows west of Demaris Lake are light gray, platy, and blocky; some flows are up to $60 \mathrm{~m}$ thlck. Phenocrysts and glomerocrysts of plagioclase (oscillatory zones in normal sequence through broad cores of An 80-65, changing abruptly to narrow rims zoned An 65-35; up to 3 mm), olfvine (up to $2 \mathrm{~mm}$ ), and clinopyroxene, all less than $1 \%$. Flows northeast of Demaris Lake contain similar phenocrysts but up to 12,3 , and $1 \%$, respectively. Groundmass is pilotaxitic, consisting of An 30 plagioclase with intergranular clinopyroxene, magnetite, and brown glass. Flow units were produced from a cinder cone, now a glaciated remnant at $7600^{\prime}$ elevation, southeast base of Middle Sister. Overlain by basalt porphyry of Middle Sister (PsBsLa6) and underlain by andesite lava of Demaris Lake PsAnLal1). Normal paleomagnetic polarity. Analyses 252, 255, 583, 605, 606, 607, 608, 645, 646; average 1045. Geologic map subdivision 7 and quadrangle west.

PsBALa37 Basaltic andesite lava from dikes exposed on cleaver between Hayden and Diller Glaciers at $8600^{\prime}$ elevation on the east side of Middle Sister. Silica 55. Lavas thin, scoriaceous, and oxidized near vents, dense and blocky at lower elevations. Phenocrysts of plag1oclase (12-13\%; An 65 in resorbed cores mantled by normal zones to An 40 rims; up to $0.6 \mathrm{~mm}$ ) and olivine (1-2\%; up to $0.5 \mathrm{~mm})$. Groundmass An 35 plagloclase with intergranular olivine, pyroxene, and magnetite. One of several Fe- and Ti-rich flows of Middle Sister. Analyses 582, 585; average 1051. Geologic map subdivision 7 and quadrangle west.

PsBALa38 Basaltic andesite lava from small glaciated shelf at 6300 ' elevation, south of Demaris Lake. Silica 54. Blocky lavas, black where fresh, gray to white on weathered surfaces. Phenocrysts of plagioclase (16-18\%; An 80-75 cores, zoned normally to rims of An $75-65$; up to $3 \mathrm{~mm}$ ) and olivine (less than $1 \%$; up to $1 \mathrm{~mm}$ ). Overlain by andeste lava of Demaris Lake (PsAnLall) and rhyodacite lava east of Chambers Lakes (PsRdLal). Analysis 251. Geologic map subdivision 7.

PsBALa39 Basaltic andesite lava overlying Shevlin Park Tuff in canyon of North Fork Squaw Creek. Slilica 55. Flows up to $10 \mathrm{~m}$ thick, blocky, gray to black. Phenocrysts of plagioclase (4-5\%; normal oscillatory zones from An 65 to An 50, some resorbed cores; up to $1 \mathrm{~mm}$ ), olivine (1\%; $1 \mathrm{~mm}$ ), and clinopyroxene (less than $1 \%$; up to $0.5 \mathrm{~mm}$ ). Sparse glomerocrysts. Intergranular groundmass of An 50 plagioclase, pyroxene, olivine, magnetite, and glass. Overlain by andesite lava of Demaris Lake (PsAnLal1). Normal paleomagnetic polarity. Analysis 230 . Geologic map subdivision 8.

PsBAPc40 Glaciated remnant of basaltic anveste cinder cone exposed in bed of Squaw Creek at $4680^{\prime}$ elevation. Silica 55. One of several cone reminants which occur on the floor of Squaw Creek canyon near the mouth of North Fork Squaw Creek. Some cones rest upon andesite lava of lower Squaw Creek (PsAnLal0) and some are overlain by it. Analysis 219. Geologic map subdivisions 5 and 8.

PsBAPc41 Basaltic andesite cinder cone in S.E. corner of N.W. Broken Top quadrangle. Silica 55. Southernmost of three cones associated with glaciated lavas west of Three Creek Butte. Sparse microphenocrysts of plagioclase and trace clinopyroxene. Analyses 238 and 248 ; average 1049 . Geologic map subdivision 9. 
PsAnLal Two-pyroxene andesite lavas from South Sister volcano. Silica 59-63. Gray, platy, flowbanded interiors with blocky margins of black vitrophyre. Phenocrysts of plagioclase, clinopyroxene, orthopyroxene, and magnetite from this unit have been described previously (Taylor, 1978). This is one of the youngest lava units in N. W. Broken Top quadrangle; it moved from the lower eastern flanks of South Sister, northeastward around the rhyodacite dome of PsRdLal, and into the valley of Squaw Creek. Analysis 250; 7 other analyses from quadrangles S. and S.W. are averaged in 1018. Geologic map subdivisions 7,8 and quadrangles S. and S.W.

PsAnLa10 Clinopyroxene-bearing transitional andesite-dacite lavas at the confluence of North Fork and South Fork of Squaw Creek. Silica 62-63. Light gray to yellow on weathered surfaces. Up to $60 \mathrm{~m}$ thick. Phenocrysts of plagioclase (18-20\%; reverse-zoned cores of An 30-45 are surrounded by broad normal-zoned rims of An 30-25; resorbed band of patchy zonation is common just instde An 45-30 discontinuity; up to $4 \mathrm{~mm}$ ), clinopyroxene $(4 \%$; up to $1.5 \mathrm{~mm})$, magnetite (1-2\%; 1 ess than $0.5 \mathrm{~mm})$, and orthopyroxene (less than $1 \%$; up to $1 \mathrm{~mm}$ ). Glomerocrysts of plagloclase, pyroxenes, and magnetite often contain olivine crystals up to $3 \mathrm{~mm}$ which are jacketed by orthopyroxene. Light-colored cognate inclusions are abundant. Pilotaxitic groundmass of plagioclase laths (An 20) with intergranular pyroxene, magnetite, and glass. One of the lowest stratigraphic units exposed In N.W. Broken Top quadrangle; overlain by lavas of PsBALa32 and PsBALa33. Normal paleomagnetic polarity. Analyses 216, 220; average 1042. Geologic map subdivisions 5, 6, and 8 .

PsAnLal1 Two-pyroxene transitional andesite-dacite lavas extending from Demaris Lake, $9 \mathrm{~km}$ down Squaw Creek valley. Discontinuous remnants of intracanyon flows from early South Sister volcano. Silica 61-65, average 62.7. Several flow units, 20-60 m thick with brown-to-gray platy interlors and black glassy margins. Phenocrysts and glomerocrysts of plagioclase (8-14\%; An 50-45 cores with patchy zoning, surrounded by broad rims of An 35-30; up to $4 \mathrm{~mm}$, rounded and resorbed), clinopyroxene (2-5\%, up to $2 \mathrm{~mm}$ with rims of granular clinopyroxene), orthopyroxene (up to $2 \%$, usually less than $1 \mathrm{~mm}$ ), and magnetite (chiefly $0.5 \mathrm{~mm}$ octahedral inclusions in pyroxene). P1lotaxitic groundmass of An 35-30 plagioclase laths with intergranular pyroxene, magnetite, and light brown glass. Rests upon basaltic andesite lavas of PsBALa32, 33, 38, 39 and North Sister (PsBALa31). Overlain by rhyodacite dome of PsRDLal and by lavas from glaciated cone at S.E. base of Middle Sister (PsBALa36). Normal paleomagnetic polarity. Analyses 215, 227, 228, 249, 253, 254, 377; average 1046. Geologic map subdivisions $5,6,7$, and 8 .

PsanPil2 Shevlin Park Tuff. S1lica 59-62. A black andesitic welded tuff, 10-12 m thick, consisting of black pumiceous bombs, andesite scorfa, and white rhyodacite fragments in an unsorted matrix of black, gray, yellow, and red oxidized andesitic ash. Phenocrysts in the black pumice total less than 1 percent, but include plagloclase (faint normal zoning; An 46-38; up to $2 \mathrm{~mm}$ ), hypersthene (En 64; up to $2 \mathrm{~mm}$ ), olivine (Fo 78; up to $1 \mathrm{~mm}$ ) and titanomagnetite (up to $0.5 \mathrm{~mm}$ ). Shev1in Park Tuff, as exposed in North Fork Squaw Creek canyon,. Is firmly welded, displays eutaxitic textures, but has not collapsed to a vitrophyre. Rests on lava of PsBALa33; overlain by PsBALa39. Normal paleomagnetic polarity. Analysis 226; average 1048 includes 4 analyses from Sheviin Park Tuff near Bend. Geologic map subdivision 8 and quadrangles N.E., E., and S.E.

Units of Pleistocene Rhyodacite

PsRdLal Glaclated rhyodacite dome east of Chambers Lake. Silica 73. Marginal rocks are black, brown, and red flow-banded obsidian. Spherulites contain phenocryst nuclei. Interior is 
gray to pink, very fine grained, contains well developed platy fointing, and grades into a gray-towhtte, coarser grained, porous core. Plagioclase phenocrysts are rounded, resorbed, and embayed. They make up less than $1 \%$ of the rock and seldom exceed $1 \mathrm{~mm}$. Secondary silica is common in cavities. Probable source vent underlies thickest and highest part of the dome. Stratigraphically between early and late south Sister lavas (PsAnLall and PsAnLal). Average composition (Taylor, 1978) 1029. Geologic map subdivision 7 and quadrangles W., S.W., and S.

PsRdLa14 Rhyodacite lava of Squaw Creek Falls. Silica 69. Platy jointed, gray holocrystalline interiors with black glassy margins. Phenocrysts and glomerocrysts of plagioclase (3-4\%; An 30 cores mantled by normal zones to An 25; up to $2 \mathrm{~mm}$ ), orthopyroxene (stout prisms to $1 \mathrm{~mm}$ ), c11nopyroxene (slender needles to $1.5 \mathrm{~mm})$, and magnetite $(0.05 \mathrm{~mm})$. Orthopyroxene exceeds clinopyroxene in abundance, but both are less than one percent. Analyses 229, 369, 370; average 1047. Geologic map subdivision 8 .

PsRdLa15 Western member of Three Creek Butte and Melvin Butte group of rhyodacite domes. Silica 74-75. White to yellow brown, flow banded. Sparse phenocrysts of An 30 plagioclase up to $1.5 \mathrm{~mm}$ with inclusions of altered amphibole. Magnetite granules to $0.05 \mathrm{~mm}$. Overlain by lavas of PsBALa34. Analysis 239. Geologic map subdivision 9 and quadrangle east.

\section{REFERENCES}

Armstrong, R. L., Taylor, E. M., Hales, P. 0., and Parker, D. J., 1975, K-Ar dates for volcanic rocks, central Cascade Range of Oregon: Isochron/West, No. 13, p. 5-10.

Bacon, C. R., 1983, Eruptive history of Mount Mazama and Crater Lake caldera, Cascade Range, U.S.A.: Journal of Volcanology and Geothermal Research, Vol. 18, p. 57-1.15.

H111, B. D., 1985, Petrology of the Bend pumice and Tumalo tuff, a Ple1stocene Cascade eruption involving magma mixing: Corvallis, Oregon State University master's thesis, $101 \mathrm{p}$.

Sarna-Wojcick1, A. M., Morrison, S. D., Meyer, C. E., and Hillhouse, J. W., 1987, Correlation of upper Ceneozolc tephra layers between sediments of the western United States and eastern Pacific Ocean and comparison with biostratigraphic and magnetostratigraphic age data: Geological Society of America Bulletin, Vol. 98, p. 207-223.

Scott, W. E., 1977, Quaternary glaciation and volcanism, Metollus River area, Oregon: Geological Society of America Bulletin, Vol. 88, p. 113-124.

, 1987, Holocene rhyodacite eruptions on the flanks of South Sister volcano, Oregon: Geological Soclety of America Special Paper 212, p. 35-53.

Shackleton, N. J. and Opdyke, N. E., 1973, Oxygen isotope and paleomagnetic stratigraphy of equatorial Pacific core V28-238: Oxygen isotope temperatures and ice volumes on a $10^{5}$ and $10^{6}$ year scale: Quaternary Research, Vol. 3, p. 39-55.

Shelley, D., 1975, Manual of optical mineralogy: Elsevier, Amsterdam, 239 p.

Smith, G. A., 1986, Stratigraphy, sedimentology, and petrology of Neogene rocks in the Deschutes basin, central Oregon: A record of continental-margin volcanism and its influence on fluvial sedimentation in an arc-adjacent basin: Corvallis, Oregon State University PhD dissertation, $467 \mathrm{p}$. 
Smith, G. A., Snee, L. W., and Taylor, E. M., 1987, Stratigraphic, sedimentologic, and petrographic record of late Miocene subsidence of the central Oregon High Cascades: Geology, Vo1. 15, p. 389-392.

Taylor, E. M., 1968, Radiocarbon ages of Blue Lake Crater, Four-in-One Crater, and Lost Lake cones, Oregon: Contributions to Washington State University Natural Radiocarbon Measurements I: Radiocarbon, Vo1. 10, p. 493-494.

, 1978, Field geology of S. W. Broken Top quadrangle, Oregon: Special Paper 2, Oregon Department of Geology and Mineral Industries, p. 1-50.

, 1980, High Cascade ash-flow tuffs and pumice deposits in the vicinity of Bend, Oregon: Geological Soclety of America Abstracts with Programs, Vol. 12, p. 155.

, 1981, Central High Cascade roadside geology, Bend, Sisters, McKenzie Pass, and Santiam Pass, Oregon, in: Johnston, D. A. and Donnelly-Nolan, J., eds., Guides to some volcanic terranes in Washington, Idaho, Oregon, and northern California: U.S. Geological Survey Circular 838, p. 55-83.

Tob1, A. C., 1963, Plagloclase determination with the ald of the extinction angles in sections normal to (010): American Journal of Science, Vo1. 261, p. 157-167.

Von Burri, C., Parker, R. L., and Wenk, E., 1969, Die optische orientierung der plagioclase: Birkhauser Verlag, Basel, 334 p.

Williams, H., 1944, Volcanoes of the Three Sisters region, Oregon Cascades: University of Cal1fornia Publications, Department of Geological Sciences Bulletin, Vol. 27, p. 37-84.

Wise, W. S., 1969, Geology and petrology of the Mt. Hood area: a study of High Cascade volcanism: Geological Soclety of America Bulletin, Vo1. 80, p. 969-1006.

\section{ACKNOWLEDGEMENT}

Brittain E. Hi1l and George R. Priest offered helpful suggestions for clarification of text and map. Therese Belden patiently and skillfully provided typewritten copy. 
APPENDIX 1

Chemical Analyses of Rocks from N.W. Broken Top Quadrangle

\begin{tabular}{|c|c|c|c|c|c|c|c|c|c|c|c|}
\hline 6 & 9 & 16 & 31 & 35 & 36 & 37 & 38 & 51 & 59 & 60 & 61 \\
\hline 17.0 & 16.8 & 17.1 & 15.8 & 17.1 & 17.7 & 15.7 & 17.0 & 18.1 & 16.8 & 15.8 & 15.9 \\
\hline 4.5 & 4.8 & 4.6 & 3.3 & 3.5 & 5.6 & 3.8 & 5.5 & 5.2 & 6.8 & 4.2 & 7.4 \\
\hline 8.0 & 8.3 & 8.3 & 6.7 & 7.7 & 10.6 & 6.9 & 9.3 & 8.4 & 9.2 & 7.4 & 9.4 \\
\hline$\overline{99.85}$ & $\overline{99.75}$ & $\overline{99.10}$ & 99.35 & $\overline{99.50}$ & $\overline{99.85}$ & 99.25 & 100.05 & $\overline{99.35}$ & 99.65 & 99.60 & 99.50 \\
\hline
\end{tabular}

\begin{tabular}{|c|c|c|c|c|c|c|c|c|c|c|c|}
\hline 66 & 69 & 70 & 73 & 77 & 82 & 150 & 210 & 211 & .212 & 213 & 214 \\
\hline 57.6 & 56.9 & 54.2 & 54.2 & 56.9 & 55.4 & 56.5 & 56.8 & 53.8 & 54.7 & 54.5 & 56.5 \\
\hline 1.65 & 1.65 & 1.00 & 1.00 & 1.40 & 1.10 & 1.20 & 1.25 & 1.40 & 1.30 & 1.00 & 1.65 \\
\hline 16.9 & 16.4 & 17.9 & 18.3 & 16.5 & 17.3 & 16.6 & 17.6 & 17.3 & 17.4 & 17.7 & 16.8 \\
\hline 9.0 & 9.0 & 8.0 & 8.0 & 8.4 & 8.4 & 8.8 & 8.0 & 8.7 & 8.0 & 7.2 & 8.8 \\
\hline 3.0 & 3.0 & 5.0 & 4.7 & 3.8 & 4.8 & 3.8 & 4.0 & 5.7 & 5.9 & 5.6 & 3.4 \\
\hline 6.7 & 6.7 & 8.6 & 9.0 & 7.8 & 8.9 & 6.6 & 6.8 & 8.5 & 8.6 & 8.2 & 6.7 \\
\hline 4.2 & 4.2 & 4.1 & 3.4 & 3.7 & 3.6 & 4.6 & 4.6 & 3.7 & 3.7 & 4.5 & 4.8 \\
\hline 0.70 & 1.10 & 0.65 & 0.45 & 0.90 & 0.75 & 1.00 & 1.20 & 0.70 & 0.65 & 0.85 & 0.95 \\
\hline 99.75 & 98.95 & 99.45 & 99.05 & 99.40 & 100.25 & 99.10 & 100.25 & 99.80 & 100.25 & 99.55 & 99.60 \\
\hline
\end{tabular}

\begin{tabular}{|c|c|c|c|c|c|c|c|c|c|c|c|c|}
\hline & 215 & 216 & 217 & 218 & 219 & 220 & 221 & 222 & 223 & 224 & 226 & 227 \\
\hline $\mathrm{SiO}_{2}$ & 62.0 & 62.3 & 53.1 & 54.5 & 55.0 & 62.3 & 57.9 & 56.8 & 55.9 & 54.2 & 61.5 & 62.0 \\
\hline & 1.15 & 1.00 & 1.35 & 0.95 & 1.20 & 0.75 & 1.70 & 1.60 & 1.80 & 1.55 & 1.30 & 1.40 \\
\hline & 16.6 & 16.5 & 17.6 & 18.7 & 17.4 & 16.1 & 15.6 & 16.2 & 16.1 & 18.2 & 15.2 & 16.6 \\
\hline & 6.0 & 5.6 & 8.9 & 7.2 & 8.1 & 5.5 & 8.5 & 8.8 & 9.3 & 8.8 & 6.9 & 6.2 \\
\hline $\mathrm{g} O$ & 2.1 & 1.8 & 6.0 & 4.8 & 4.6 & 2.1 & 2.9 & 3.5 & 3.6 & 3.3 & 2.6 & 2.2 \\
\hline $\mathrm{aO}$ & 4.8 & 4.0 & 8.3 & 8.7 & 7.2 & 4.1 & 5.8 & 6.5 & 6.7 & 8.3 & 5.4 & 5.2 \\
\hline 0 & 5.3 & 6.4 & 4.0 & 4.1 & 3.9 & 6.2 & 5.3 & 5.0 & 4.5 & 4.7 & 5.2 & 4.6 \\
\hline & 1.85 & 1.70 & 0.50 & 0.60 & 1.05 & 1.60 & 1.30 & 1.00 & 1.15 & 0.70 & 1.40 & 1.65 \\
\hline Total & $\overline{99.80}$ & $\overline{99.30}$ & 99.75 & $\overline{99.55}$ & 98.45 & $\overline{98.65}$ & 99.00 & $\overline{99.40}$ & 99.05 & 99.75 & 99.50 & 99.85 \\
\hline
\end{tabular}

\begin{tabular}{|c|c|c|c|c|c|c|c|c|c|c|c|c|}
\hline & 228 & 229 & 230 & 231 & 234 & 236 & 238 & 239 & 240 & 248 & 249 & 250 \\
\hline $\mathrm{SiO}_{2}$ & 64.1 & 68.9 & 54.8 & 54.5 & 54.8 & 56.7 & 55.0 & 74.4 & 56.0 & 54.7 & 62.6 & 63.9 \\
\hline $\mathrm{TiO}_{2}^{2}$ & 1.00 & 0.50 & 1.30 & 1.00 & 1.00 & 1.25 & 1.00 & 0.15 & 1.60 & 1.10 & 1.00 & 1.00 \\
\hline & 16.4 & 15.5 & 17.1 & 17.7 & 17.7 & 16.9 & 17.8 & 13.9 & 16.4 & 17.7 & 16.3 & 16.2 \\
\hline reu & 5.2 & 3.5 & 7.2 & 7.5 & 7.8 & 8.3 & 7.8 & 1.6 & 9.4 & 7.4 & 5.5 & 5.2 \\
\hline MgO & 1.5 & 0.5 & 5.8 & 5.4 & 5.0 & 3.9 & 5.1 & 0.1 & 3.9 & 5.2 & 1.8 & 1.5 \\
\hline $\mathrm{CaO}$ & 4.1 & 1.9 & 7.8 & 8.2 & 8.2 & 7.0 & 7.8 & 0.8 & 7.2 & 7.7 & 4.7 & 3.9 \\
\hline $\mathrm{Na}, \mathrm{O}$ & 5.1 & 6.4 & 4.0 & 4.2 & 4.1 & 4.5 & 3.9 & 5.2 & 4.2 & 4.3 & 5.2 & 5.2 \\
\hline 2 & 2.00 & 2.30 & 1.05 & 0.64 & 0.45 & 0.90 & 0.65 & 3.20 & 0.80 & 0.60 & 2.00 & 2.05 \\
\hline Tótal & 99.40 & 99.50 & 99.05 & 99.14 & 99.05 & 99.45 & 099.05 & 99.35 & 99.50 & 98.70 & 99.10 & 98.95 \\
\hline
\end{tabular}


APPENDIX 1 (continued)

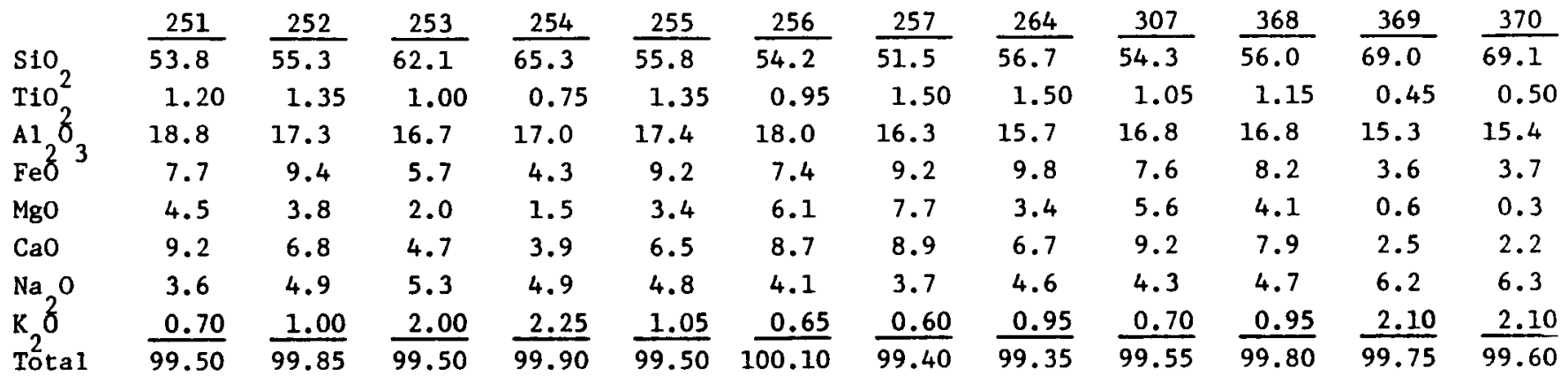

\begin{tabular}{|c|c|c|c|c|c|c|c|c|c|c|c|c|}
\hline & 373 & 374 & 375 & 376 & 377 & 378 & 379 & 489 & 492 & 543 & 544 & 545 \\
\hline S10 & 53.6 & 56.5 & 54.0 & 54.8 & 61.0 & 54.2 & 54.4 & 53.7 & 57.2 & 54.9 & 54.9 & 55.0 \\
\hline $\mathrm{TiO}^{2}$ & 1.10 & 1.65 & 1.10 & 1.00 & 1.15 & 0.95 & 1.15 & 1.15 & 1.65 & .1 .00 & 1.10 & 1.05 \\
\hline $\mathrm{Al}_{2} \mathrm{O}_{2}$ & 17.5 & 16.3 & 17.4 & 17.9 & 16.2 & 17.8 & 16.7 & 17.2 & 16.0 & 17.6 & 17.1 & 17.4 \\
\hline $\mathrm{FeO}^{3}$ & 8.0 & 9.2 & 8.2 & 7.3 & 6.4 & 7.4 & 8.2 & 8.0 & 9.5 & 7.5 & 7.8 & 7.8 \\
\hline $\mathrm{MgO}$ & 5.7 & 3.3 & 5.5 & 5.4 & 2.4 & 6.1 & 5.8 & 5.2 & 4.2 & 5.7 & 5.6 & 5.4 \\
\hline $\mathrm{CaO}$ & 8.5 & 6.5 & 8.4 & 8.6 & 5.8 & 8.9 & 9.0 & 8.3 & 6.4 & 9.0 & 8.6 & 8.8 \\
\hline $\mathrm{Na} O$ & 4.0 & 4.8 & 3.6 & 4.2 & 4.8 & 3.8 & 3.9 & 3.6 & 4.2 & 3.9 & 4.3 & 4.0 \\
\hline & 0.65 & 1.15 & 0.70 & 0.65 & 1.65 & 0.60 & 0.80 & 0.85 & 1.30 & 0.55 & 0.70 & 0.70 \\
\hline Total & 99.05 & $\overline{99.40}$ & 98.90 & 99.85 & 99.40 & 99.75 & 99.95 & 98.00 & 100.45 & 100.15 & 100.10 & 100.15 \\
\hline
\end{tabular}

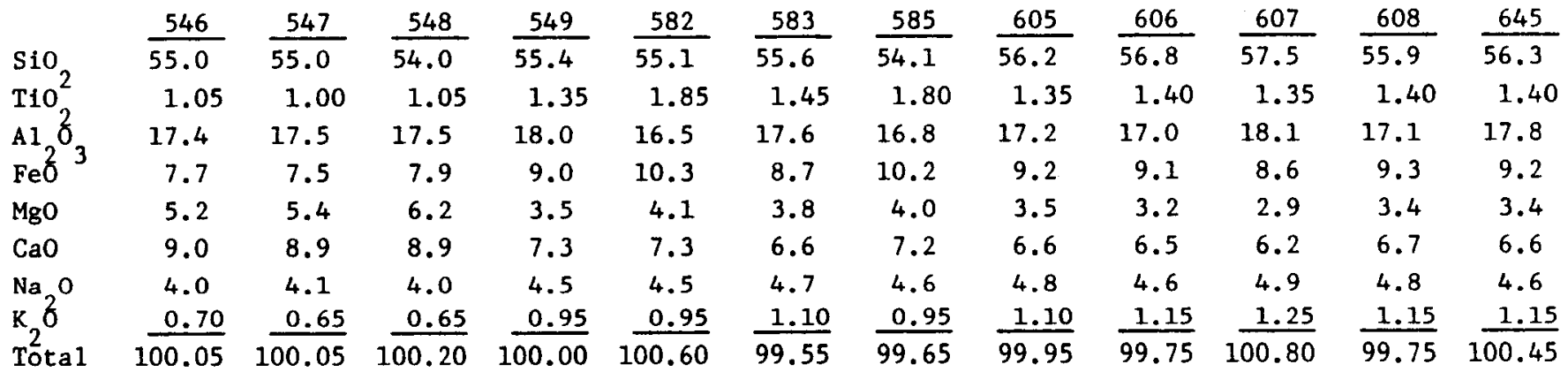

\begin{tabular}{|c|c|c|c|c|c|c|c|c|c|c|c|c|}
\hline & 646 & 1013 & 1018 & 1029 & 1036 & 1037 & 1038 & 1039 & 1040 & 1041 & 1042 & 1043 \\
\hline $\mathrm{SiO}$ & 55.7 & 54.7 & 61.3 & 73.1 & 56.3 & 53.8 & 56.8 & 51.8 & 57.0 & 54.7 & 62.3 & 56.7 \\
\hline & 17.1 & 18.4 & 16.7 & 14.5 & 17.1 & 17.4 & 16.2 & 16.3 & 16.7 & 17.4 & 16.3 & 16.2 \\
\hline $\mathrm{MgO}$ & 4.0 & 5.2 & 2.4 & 0.3 & 4.6 & 5.5 & 3.7 & 7.3 & 3.1 & 5.6 & 2.0 & 3.6 \\
\hline $\mathrm{CaO}$ & 6.6 & 7.9 & 5.2 & 1.5 & 8.2 & 8.4 & 7.1 & 9.2 & 6.7 & 8.8 & 4.1 & 6.6 \\
\hline Tótal & 99.50 & 99.90 & 100.05 & $99.95^{\circ}$ & 99.70 & 98.80 & 99.65 & 99.45 & 99.35 & 99.95 & 99.15 & 99.35 \\
\hline
\end{tabular}


APPENDIX 1 (continued)

\begin{tabular}{|c|c|c|c|c|c|c|c|c|c|}
\hline & 1044 & 1045 & 1046 & 1047 & 1048 & 1049 & 1050 & 1051 & 1052 \\
\hline $\mathrm{SiO}_{2}$ & 54.7 & 56.1 & 62.7 & 69.0 & 60.8 & 54.9 & 56.3 & 54.6 & 52.4 \\
\hline $10^{2}$ & 1.00 & 1.40 & 1.05 & 0.50 & 1.40 & 1.05 & 1.18 & 1.83 & 1.38 \\
\hline 1,8 & 17.9 & 17.5 & 16.5 & 15.4 & 15.3 & 17.8 & 16.7 & 16.7 & 18.3 \\
\hline 3 & 7.9 & 9.1 & 5.6 & 3.6 & 7.6 & 7.6 & 8.5 & 10.3 & 8.9 \\
\hline 50 & 5.0 & 3.5 & 1.9 & 0.5 & 2.6 & 5.2 & 4.0 & 4.1 & 5.9 \\
\hline $\mathrm{aO}$ & 8.6 & 6.6 & 4.7 & 2.2 & 5.5 & 7.8 & 7.3 & 7.3 & 8.4 \\
\hline la 0 & 3.8 & 4.7 & 5.0 & 6.3 & 5.1 & 4.1 & 4.7 & 4.6 & 4.0 \\
\hline & 0.60 & 1.10 & 1.90 & 2.20 & 1.35 & 0.65 & 0.98 & 0.95 & 0.65 \\
\hline tal & $\overline{99.50}$ & $1 \overline{00.00}$ & $\overline{99.35}$ & $\overline{99.70}$ & $\overline{99.65}$ & $\overline{99.10}$ & $\overline{99.66}$ & $\overline{100.38}$ & $\overline{99.93}$ \\
\hline
\end{tabular}


APPENDIX 2

Locations of Analysed Rocks, N.W. Broken Top Quandrangle

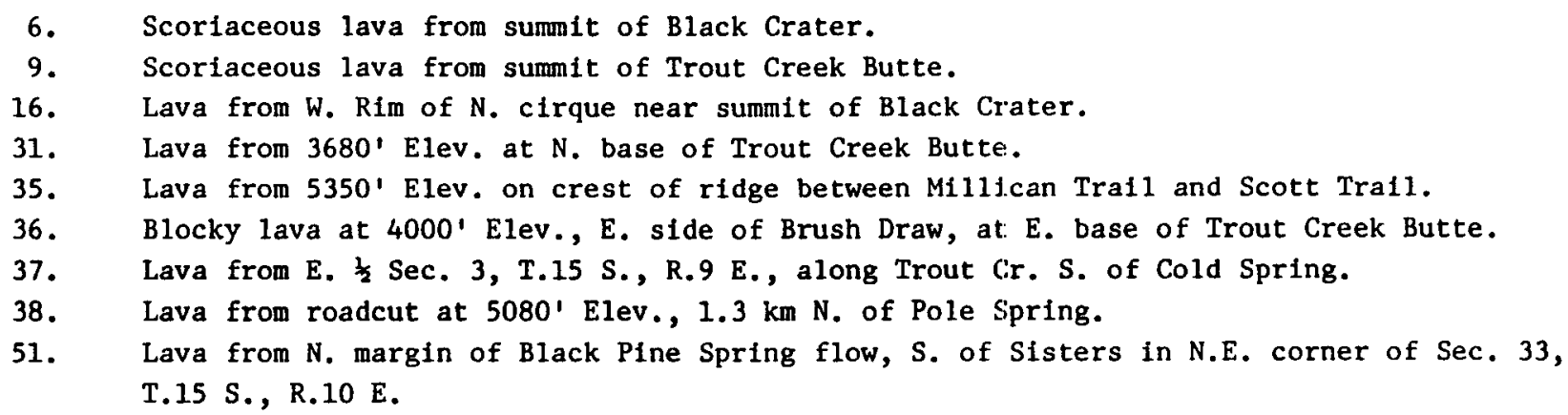

59. Diktytaxitic lava from cliffs at $388^{\prime}$ Elev., N.W. of Squaw Cr. in S.W. $\frac{1}{2}$ of Sec. 31 , T.15 S., R.10 E.

60. Lava $0.1 \mathrm{~km} \mathrm{N.W.} \mathrm{of} \mathrm{Cold} \mathrm{Springs.}$

61. Diktytaxitic lava $0.3 \mathrm{~km}$ W. of Spruce Spring.

66. Lava from cliffs in N.W. bank of Squaw Cr. at $4040^{\prime}$ Elev.

69. Lava from N.W. bank of Squaw Cr. at 4200 ' Elev.

70. Fine-grained lava from quarry in N. margin of Black Pine Spring flow, N.W. $\frac{1}{4}$, Sec. 11, T.16 S., R. 9 E.

73. Lava from high knob on surface of Black Pine Spring flow, S. E. 立, Sec. 31, T.15 S., R.10 E.

77. Lava from roadcut on S.W. side of Trout Creek Swamp.

82. Lava from N.E. terminus of Black Pine Spring flow, cut of logging road, N.W. corner of Sec. 26, T.15 S., R. 10 E.

150. Cinders from glaciated cone at $6720^{\prime}$ Elev., center Sec. 9, T.17 S., R.9 E., 2.8 km N.W. of Three Creek Lake.

210. Platy lava at $6260^{\prime}$ Elev., center of W. boundary of Sec. 7, T.17 S., R.9 E.

211. Vesicular, highly porphyritic lava from cut of logging road at $4500^{\prime}$ Elev., E. center of Sec. 17, T.16 S., R.9 E.

212. Coarse-grained lava from valley-filling flow, N.W. of Alder Cr. at 5700' Elev.

213. Lava from falls on Alder Cr, at $6000^{\prime}$ Elev.

214. Volcanic bomb from quarry in cinder cone E. of Pole Cr., Sec. 4, T.16 S., R.9 E.

215. Lava from $4750^{\prime}$ Elev. on Squaw Cr., Sec. 29, T.16 S., R.9 E.

216. Platy lava in bed of Squaw Cr. at $4560^{\prime}$ Elev., N.E. 交 of Sec. 20, T.16 S., R.9 E.

217. Lava from small quarry, W. side of logging road at $4680^{\prime}$ Elev., E. center of Sec. 20 , T.16 S., R.9 E.

218. Lava from base of cliffs at $4900^{\prime}$ Elev., W. side of Squaw Cr., S. center of Sec. 20 , T.16 S., R.9 E.

219. Oxidized cinders from remnant of cone in bed of Squaw Cr. at 4680' Elev., Sec. 10, T.16 S., R. $9 \mathrm{E}$.

220. Platy lava from N. Bank of Squaw $\mathrm{Cr}$. at confluence with North Fork.

221. Platy lava from base of cliffs at 4800' Elev., E. side of prominence between Snow Cr. and Squaw Cr., N.W. $\frac{1}{2}$ of Sec. 21, T.16 S., R.9 E.

222. Platy lava from cliffs at $4840^{\prime}$ Elev., W. side of Snow Cr., center of Sec. 21 , T.16 S., R. 9 E.

223. Platy lava E. of Snow Cr. at 5100' Elev., N.W. Sec. 28, T.16 S., R.9 E.

224. Lava below Shevlin Park Tuff at 5000' Elev. on N. Fork Squaw Cr., N.W. $\frac{1}{2}$ Sec. 29, T.16 S., R. 9 E.

226. Pumice fragment from base of Shevlin Park Tuff at $5112^{\prime}$ Elev., S. bank of N. Fork Squaw Cr. 227. Platy lava at 5340' Elev., S. side of N. Fork Squaw Cr., S.E. Sec. 30, T.16 S., R.9 E. 
Black, glassy, columnar-jolnted lava at $5260^{\prime}$ Elev., $0.1 \mathrm{~km} \mathrm{~N}$. of upper falls of S. Fork Squaw Cr., N.E. 光 Sec. 31, T.16 S., R. 9 E.

229. Platy lava at $5460^{\prime}$ Elev., $0.4 \mathrm{~km} \mathrm{E.} \mathrm{of} \mathrm{Squaw} \mathrm{Cr.} \mathrm{Falls.}$

230. Lava from 5480' Elev. on N. Fork Squaw Cr., S. center of Sec. 30, T.16 S., R.9 E.

231. Lava from outcrop at $4650^{\prime}$ Elev., surrounded by Pleistocene moraine in $N$. center of Sec. 15 , T. 16 S., R.9 E.

234. Cinders from source cone of Black Pine Spring flow, S.E. $\frac{1}{4}$ of Sec. 15, T.15 S., R.9 E.

236. Scorfaceous lava from surface of flow W. of Melvin But:te, W. central Sec. 23, T.16 S., R.9 E.

238. Lava from vent area at $5820^{\prime}$ Elev., associated with cones $2-3 \mathrm{~km} \mathrm{~N}$. of Three Creek Lake, center of Sec. 35, T.16 S., R.9 E.

239. Blocky lava from W. flank of eroded and nearly covered silicic volcanic dome W. of Three Creek Butte, N.E. Sec. 34, T.16 S., R.9 E.

240.

248 .

249.

250.

251.

252.

253.

254.

255.

256.

257.

264.

307.

368.

369.

370 .

373.

374.

375.

376 .

377 .

378.

379.

489.

492.

543.

544.

545.

546.

547.

548.

549. Lava from cut along Three $\mathrm{Cr}$. Lake highway at 5260' Elev., S.E. $\frac{1}{4}$ Sec. 27, T.16 S., R.9 E. Oxidized cinders from cone quarry, N.W. Sec. 2, T.17 S., R.9 E.

Black glassy lava from crest of ridge at $5660^{\prime}$ Elev., N. central Sec. 31, T.16 S., R.9 E. Lava from crest of ridge at $5650^{\prime}$ Elev., central Sec. 31, T.16 S., R.9 E.

Lava from glaciated cliffs at $6280^{\prime}$ Elev., $0.9 \mathrm{~km} \mathrm{S.} \mathrm{of} \mathrm{Demaris} \mathrm{Lake.}$

Blocky lava from base of cliffs at $6460^{\prime}$ Elev., $0.6 \mathrm{~km} \mathrm{S.W.} \mathrm{of} \mathrm{Demaris} \mathrm{Lake.}$

Black glassy lava at $6350^{\prime}$ Elev., $0.5 \mathrm{~km} \mathrm{S.W.} \mathrm{of} \mathrm{Demaris} \mathrm{Lake.}$

Glaciated platy lava at $6060^{\prime}$ Elev., $0.4 \mathrm{~km}$ N.E. of Demaris Lake.

Lava from edge of cliffs at $6200^{\prime}$ Elev., $0.9 \mathrm{~km} \mathrm{N.E.} \mathrm{of} \mathrm{Demaris} \mathrm{Lake.}$

Lava exposed in N. bank of N. Fork Squaw Creek at 5880' Elev., E. of Demaris Lake.

Diktytaxitic lava at $4680^{\prime}$ Elev, on Pole Creek. W. $\frac{1}{2}$ Sec. 4, T.16 S., R.9 E.

Lava from thin scorlaceous flow at $6150^{\prime}$ Elev. on $S$. side of cinder cone between North and South Matthieu Lakes.

Lava at $7080^{\prime}$ Elev. at N. base of N.E. ridge, North Sister.

Glaciated lava at $6230^{\prime}$ Elev. on Park Meadow Trail, S. central Sec. 4, T.17 S., R.9 E.

Platy lava from lip of Squaw Creek Falls at $5600^{\prime}$ Elev.

Platy lava from upper falls of E. Fork Park Creek, at $5680^{\prime}$ Elev.

Lava from $5700^{\prime}$ Elev. on S.E. side of Mililican Crater.

Lava from 5560' Elev, on crest of ridge between Millican and Scott Trails.

Glaciated lava in cut of logging road, N.E. Sec. 31, X.15 S., R.9 E.

Lava at $6680^{\prime}$ Elev. on crest of S.E. ridge, North Sister.

Black glassy crust of lava flow exposed in bed of N. Jork Squaw Creek at 6480' Elev.

Lava exposed in N. bank of N. Fork Squaw Creek at $64200^{\prime}$ Elev.

Lava from glaciated knob at $6200^{\prime}$ Elev., $1.5 \mathrm{~km}$ N.N.E. of Demaris Lake.

Lava from 5800' Elev. on S.W. slope of Millican Crater.

Glaciated lava at E. base of cinder cone, E. of North Matthieu Lake.

Lava at $7300^{\prime}$ Elev., E. ridge of North Sister.

Dike at $7500^{\prime}$ Elev., E. ridge of North Sister.

Dike at $8020^{\prime}$ Elev., crest of N.E. ridge of North Sister.

Dike at $7820^{\prime}$ Elev., N.E. ridge of North Sister.

Lava at $7600^{\prime}$ Elev., N.E. ridge of North Sister.

Basal lava in stack of thin flows at $7050^{\prime}$ Elev. on $N$. Fork of Squaw Creek.

Glaciated lava on ridge crest at $6940^{\prime} \mathrm{Elev} ., \mathrm{S}$. of N. Fork of Squaw Creek, $0.5 \mathrm{~km} \mathrm{E.} \mathrm{of}$

Diller Glacier terminal moraine.

582. Lava from N. side of N. Fork of Squaw Creek at $6600^{\prime}$ Elev.

583. Lava from bed of $\mathrm{N}$. Fork of Squaw Creek at $6640^{\circ}$ Elev., $1.3 \mathrm{~km} \mathrm{N.W.} \mathrm{of} \mathrm{Demaris} \mathrm{Lake.}$

585. Lava from crest of cleaver between Hayden and Diller Glaciers at 8600 ' Elev., E. side of Middle Sister.

605. Cinders from glaclated cone remnant, S.E. base of Middle Sister at $7760^{\prime}$ Elev.

606. Lava cap on glaciated cone remnant, S.E. base of Middle Sister at $7780^{\prime} \mathrm{Elev}$.

607. Lava at S. base of glaclated cone remnant, S.E. base of Middle Sister at $7550^{\prime}$ Elev. 
608. Lava at $7360^{\prime}$ Elev., S.E. base of Middle Sister.

645. Blocky lava from cliffs at $7040^{\prime}$ Elev., $0.2 \mathrm{~km} \mathrm{N.W.} \mathrm{of} \mathrm{Camp} \mathrm{Lake} \mathrm{at} \mathrm{head} \mathrm{of} \mathrm{S.} \mathrm{Fork} \mathrm{Squaw}$ Creek.

646. Glaclated lava from crest of ridge at $2920^{\prime} \mathrm{Elev}, 1.4 \mathrm{~km} \mathrm{~W}$. of Demaris Lake.

1013. Average of 19 basaltic andesite lavas from Broken Top volcano (Taylor, 1978).

1018. Average of 8 east-flank South Sister andesites (Taylor, 1978).

1029. Average of 3 rhyodacites E. of Chambers Lakes (Taylor, 1978).

1036. Average Black Crater basaltic andesite. Analyses 6, 16.

1037. Average Millican Crater basaltic andestte. Analyses 373, 489.

1038. Average basaltic andesite cinders and lavas from cone E. of North Matthieu Lake. Analyses $35,37,60,77,264,374,492$.

1039. Average diktytaxitic basalt of Spruce Spring. Analyses 59, 61, 257.

1040. Average basaltic andesite from cone E. of Pole Creek. Analyses 66, 69, 214.

1041. Average of 14 lava and dike rocks from E. slope of North Sister. Analyses 38, 212, 213, $256,307,376,378,379,543,544,545,546,547,548$.

1042. Average lower Squaw Creek andesite. Analyses 216, 240.

1043. Average basaltic andesite lava of E. side of Squaw Creek canyon. Analyses 221, 222, 223, $236,240$.

1044. Average Black Pine Spring lavas and cinder cone. Analyses 51, 70, 73, 82, $231,234$.

1045. Average basaltic andesite lavas W. and N.E. of Demaris Lake. Analyses 252, 255, 549, 583, $605,607,608,645,646$.

1046. Average transitional andesite-dacite lavas intracanyon to Squaw Creek. Analyses 215 , 227 , $228,249,253,254$.

1047. Average rhyodacite lavas of Squaw Creek Fal1s. Analyses 229, 369, 370.

1048. Average Shevlin Park Tuff; 4 pumlces from vicinity of Bend.

1049. Average basaltic andesite lavas and cinders from cones, $4 \mathrm{~km}$. of Three Creek Lake. Analyses $238,248$.

1050. Average basaltic andesite lava and cone, Snow Creek Ditch. Analyses $150,358$.

1051. Average basaltic andesite lavas from dikes in cleaver between Hayden and Diller Glaciers, east flank Middle Sister. Analyses 582, 585.

1052. Average of 11 lavas and dikes of Middle Sister basalt porphyry. 
